\title{
Mechanisms of absorption of caseinophosphopeptide bound iron
}

\author{
Jean-Michel Pérès, * Saïd Bouhallab, ${ }^{\dagger}$ François Bureau, ${ }^{*}$ Dominique Neuville, \\ Jean-Louis Maubois, ${ }^{\dagger}$ Ghislain Devroede, ${ }^{\S}$ Pierre Arhan, ${ }^{*}$ and Dominique Bouglé ${ }^{*}, \|$ \\ *Laboratoire de Physiologie Digestive et Nutritionnelle, Caen, France; ${ }^{\dagger}$ Laboratoire de \\ Recherches de Technologie Laitière, INRA, Rennes, France; ${ }^{*}$ Laboratoire de Biochimie A, Caen, \\ France; ${ }^{\S}$ Centre Universitaire de Santé de L'Estrie, Fleurimont, Québec, Canada; and ${ }^{\| S}$ Service de \\ Pédiatrie A, Caen, France
}

\begin{abstract}
Binding iron $(\mathrm{Fe})$ to the 1-25 caseinophosphopeptide obtained from enzyme hydrolysis of $\beta$ casein $(\beta C P P)$ improves $\mathrm{Fe}$ bioavailability in the rat. To assess the mechanisms involved in its absorption, a perfused, vascularized duodenal rat loop model was used in controls and in Fe-deficient (bleeding of 25\% blood volume) rats. Inhibitors of oxidative phosphorylation [2-4 dinitrophenol (DNP)] and/or of endocytosis [phenylarsine oxide (PAO)] were added to the perfusion solution containing $50 \mu \mathrm{M} \mathrm{Fe}$ as $\beta \mathrm{CPP}$ bound $\mathrm{Fe}(\mathrm{Fe}-\beta \mathrm{CPP})$ or gluconate (Fe Gluc). Fe- $\beta$ CPP enhanced Fe uptake, reduced mucosal storage, and improved net absorption both in controls and in deficient animals. DNP reduced uptake, mucosal storage, and net absorption by the same percentage in Fe- $\beta$ CPP and Fe Gluc perfused rats in both control and Fe-deficient animals. PAO decreased uptake, mucosal storage, and net absorption of Fe- $\beta$ CPP but not of Fe Gluc. At the end of the experiment Fe serum levels were increased only in Fe Gluc animals. These results confirm the improved bioavailability of $\beta$ $C P P$ bound Fe. They suggest that at least part of its absorption can occur by a different pathway than usual Fe salts. Fe- $\beta$ CPP can be taken up by endocytosis and absorbed bound to amino acids or peptides. (J. Nutr. Biochem. 10:215-222, 1999) (C) Elsevier Science Inc. 1999. All rights reserved.
\end{abstract}

Keywords: iron; digestive absorption; caseinophosphopeptide; rat; endocytosis

\section{Introduction}

Iron $(\mathrm{Fe})$ bioavailability is usually low. It is largely determined by its interactions with other nutrients. During gastric transit, low $\mathrm{pH}$ releases $\mathrm{Fe}$ from food. In the duodenum the rise of $\mathrm{pH}$ leads to the formation of large, insoluble polymers of $\mathrm{Fe}^{3+} \mathrm{OH}$. Reducing agents such as ascorbic acid or ligands such as ascorbic acid or other weak acids can keep Fe soluble until it binds to mucosal mucin. ${ }^{1,2}$ Dietary proteins are likely to enhance $\mathrm{Fe}$ solubility when they increase its in vitro solubility and dialyzability. ${ }^{3-5}$ Whole proteins are assumed to be too large to diffuse across mucin filter. ${ }^{6}$ Therefore, they could release $\mathrm{Fe}$ too far in the intestine for efficient absorption.

Phosphoproteins present clusters of phosphorylated serine that bind calcium and other cations such as zinc and

Address correspondence to Dr. Bouglé, Service de Pédiatrie A, CHU Clémenceau, Avenue G, Clémenceau, F14033 Caen Cedex, France. Received January 12, 1998; accepted December 1, 1998.
$\mathrm{Fe}^{7-11}$; however, covalent bindings developed between $\mathrm{Fe}$ and phosphoserine are stronger (approximately 100 times) than ionic binding of zinc or calcium. ${ }^{12-14}$ In addition, Fe complexes are not dissociated by variations of $\mathrm{pH}$. Although they keep Fe soluble, they could be too large to improve its absorption. ${ }^{6}$ In fact, Hurrell et al.${ }^{15}$ showed that the low absorption rate of Fe supplied with milk proteins is improved by their enzyme hydrolysis. Enzyme digestion of caseins yields low molecular weight caseinophosphopeptides, which keep cations in a soluble form. ${ }^{12,16,17}$

Therefore, it was assumed that binding $\mathrm{Fe}$ to these peptides could improve its digestive absorption. Some conflicting results were reported on the effects of caseinophosphopeptides on calcium and zinc absorption. ${ }^{16,18-21}$ However, it should be kept in mind that these caseinophosphopeptides were not usually well characterized and that they form only weak complexes with cations other than $\mathrm{Fe} .7,9,10$

On the contrary, we used the precisely defined 1-25 caseinophosphopeptide of $\beta$-casein ( $\beta \mathrm{CPP}$ ), which contains four of the five phosphoserine residues of the native $\beta$ 
casein and can bind four atoms of Fe. ${ }^{12}$ Preliminary reports on $\mathrm{Fe}$ metabolism showed that binding $\mathrm{Fe}$ to $\beta \mathrm{CPP}$ improves its bioavailability in young deficient rats $^{22}$ and increases its absorption by the isolated, vascularized duodenal rat loop model. ${ }^{23}$ These results could not be explained only by an increased digestive solubility. The strong affinity of caseinophosphopeptides for $\mathrm{Fe}^{12,24}$ and the occurrence of biologically active peptides issued from milk proteins in plasma $^{25-27}$ suggest that $\beta$ CPP bound Fe could be absorbed by a different pathway other than non-heme Fe.

The present study was designed to assess the mechanisms involved in the mucosal step of $\beta$ CPP bound Fe absorption. For that purpose, an isolated duodenal rat loop was used. The absorption of $\beta$ CPP bound $\mathrm{Fe}$ (Fe- $\beta$ CPP) and $\mathrm{Fe}$ gluconate (Fe Gluc) was compared in normal and $\mathrm{Fe}$-deficient rats. Fe gluconate was chosen because of its well-known good bioavailability and because it remains soluble at alkaline $\mathrm{pH} .{ }^{28}$ The experiments were done in the presence of inhibitors of endocytosis [phenylarsine oxide (PAO)] and oxidative phosphorylation [2-4 dinitrophenol (DNP)] in order to study the apical membrane uptake of $\mathrm{Fe}$ and to differentiate between passive and active pathways involved in its transfer across mucosa.

\section{Materials and methods}

\section{Preparation of 1-25 caseinophosphopeptide of $\beta$ casein}

$\beta$ Casein was isolated from industrially-made sodium caseinate (Armor Protéines, Saint-Brice-en-Coglès, France) by cold solubilization $\left(\mathrm{pH} 4.5 ; 4^{\circ} \mathrm{C}\right)$, followed by ion exchange chromatography. ${ }^{10,12}$

Then, 1-25 caseinophosphopeptide $\beta$ casein was obtained by tryptic digestion of $\beta$ casein, and calcium/ethanol precipitation of the $\beta \mathrm{CPP}{ }^{28} \mathrm{Fe}$ was bound to $\beta \mathrm{CPP}$ by adding $\mathrm{FeCl}_{2}$ solution $\left[4.10^{-2} \mathrm{M}\right.$ with tenfold excess of $\mathrm{FeCl}_{2}$ solution; $\mathrm{pH}$ 5.3; 30 minutes; $25^{\circ} \mathrm{C}$ (Milli Q system, MILLIPORE, Paris, France)]. Unbound $\mathrm{Fe}$ was discarded by ultracentrifugation and dialfiltration on a regenerated cellulose membrane with a cut off of 3,000 Da (membrane SIOY3, Amicon, Lexington, MA USA). The Fe- $\beta$ $\mathrm{CPP}$ complex obtained was then freeze-dried. Chelated $\mathrm{Fe}$ and residual calcium were measured by atomic absorption spectrometry (Varian AA 1275 VARIAN, Paris, France). As expected these assays showed that 1 mole of peptide binds 4 moles of Fe. A control without $\beta$ CPP was incubated and dialyzed under the same conditions.

\section{Animals}

Adult Sprague-Dawley rats weighing 250 to $300 \mathrm{~g}$ were fed with a semi-synthetic feeding for adult rats providing $200 \mathrm{~g}$ protein as casein and $200 \mathrm{mg} \mathrm{Fe} / \mathrm{kg}$ diet (UAR, Villemoisson-sur-Orge, France). Animals had been starved for 12 hours before study but had free access to water.

A total of 16 groups ( $N=6$ by group) was studied: 8 groups of normal, nondeficient animals and 8 groups of deficient animals were perfused with one of the two forms of $\mathrm{Fe}$ [Fe gluconate ( $\mathrm{Fe}$ Gluc) or Fe- $\beta$ CPP]. Experiments were performed without (controls) or with the addition of one of the inhibitory agents (DNP, PAO) or of both.

Acute Fe deficiency was obtained by drawing $25 \%$ blood volume by two retroorbital punctures at 24-hour intervals within the 48 hours prior to the experiment.

\section{Perfusion solutions}

The composition of perfusion solution was adapted from RingerLavoisier solution. Its $\mathrm{pH}$ was 4.5 (adjusted to proximal duodenum $\mathrm{pH})$. It was isotonic to the plasma (285-300 mOsm) and contained $50 \mu \mathrm{M} \mathrm{Fe}$ as gluconate or Fe- $\beta$ CPP. When necessary DNP and PAO were added at concentrations of $500 \mu \mathrm{M}$ and $100 \mu \mathrm{M}$, respectively.

\section{Experimental design}

Anesthesia was performed with ketamine (Kétalar ${ }^{\mathrm{TM}}$, PANPHARMA, Fougerès, France), which has no effect on digestive motility. Blood was drawn by a retroorbital puncture for a blood cell count and assay of serum Fe. The duodenum was exposed by laparotomy. It was perfused through a catheter inserted into the pylorus. The effluent was collected at the angle of Treitz. Every element of the perfusion device had been previously washed with a solution of Triton $\times 100(1 \mathrm{~g} / \mathrm{L})$ to prevent any contamination. The perfusion solution was kept at $37^{\circ} \mathrm{C}$ by thermostatic control and was delivered at $0.16 \mathrm{~mL} / \mathrm{min}$, using a peristaltic pump to avoid loop distention. The perfusion lasted for 2 hours. A nonabsorbable marker (polyethylene glycol 4000, PROLABO, Paris, France) was added to assess actual net water fluxes. After 2 hours of perfusion, another retroorbital puncture was performed to measure serum Fe; then the animal was euthanized by an overdose of Doléthal ${ }^{\mathrm{TM}}$ (VETOQUINOL, Lure, France); the perfused loop was washed with saline, withdrawn, and dried in a oven until a steady weight was obtained.

\section{Sample analysis}

Fe was measured by atomic spectrometric absorption (PerkinElmer 3030 PERKIN-ELMER, Courtoboeuf, France) in the serum, perfusion solution, digestive effluent, and mucosa of the perfused segment. Tissues were digested in nitric acid at ambient temperature during 24 hours. Ringer-Lavoisier solution was used as a blank.

Polyethyleneglycol (PEG) was measured in the perfusion solution and the digestive effluent by a turbidimetric method described by Hydén. ${ }^{30} \mathrm{Fe}$ disappearance from digestive lumen (Q1: $\mu \mathrm{mol})$ was calculated as follows:

$$
\mathrm{Q} 1=\left(1-\frac{[\mathrm{PEG}]_{\mathrm{T}}}{[\mathrm{PEG}]_{\mathrm{e}}} * \frac{[\mathrm{Fe}]_{\mathrm{e}}}{\left.[\mathrm{Fe}]_{\mathrm{T}}\right)} * \mathrm{D} * \mathrm{t} *[\mathrm{Fe}]_{\mathrm{T}}\right.
$$

where $[\mathrm{PEG}]$ and $[\mathrm{Fe}]$ represent PEG and Fe concentrations in perfusion solution (T) and in the effluent (e), respectively. D and $\mathrm{t}$ are the delivery rate $(\mathrm{mL} / \mathrm{min})$ and the time of collection.

Fe stored by the mucosa $(\mathrm{Q} 2: \mu \mathrm{mol})$ during the perfusion was calculated as follows:

$$
\mathrm{Q} 2=\left([\mathrm{Fe}]_{\mathrm{m}}-[\mathrm{Fe}]_{\mathrm{m} 0}\right) * \mathrm{P}_{\mathrm{m}}
$$

where $\mathrm{m}$ is the segment of perfused intestinal mucosa and $\mathrm{P}_{\mathrm{m}}$ its dry weight; $[\mathrm{Fe}]_{\mathrm{mo}}$ is the mean Fe concentration displayed by the duodenal mucosa of a separate group of 24 rats previously perfused for 2 hours with a Fe free solution. Net Fe absorption (Fe abs: $\mu \mathrm{mol}$ ) during the perfusion was $\mathrm{Fe}$ abs $=\mathrm{Q} 1-\mathrm{Q} 2$.

\section{Statistics}

Results are expressed as mean and standard deviations. Groups were compared by two-way analysis of variance (ANOVA) and Student's $t$-test. 
Table 1 Digestive absorption of iron (Fe) provided as $\beta$ CPP (Fe- $\beta$ CPP) and gluconate (Fe Gluc) by isolated, vascularized rat loop model in Fe-deficient or normal rats

\begin{tabular}{|c|c|c|c|c|c|}
\hline & \multicolumn{2}{|c|}{ Normal } & \multicolumn{2}{|c|}{ Fe Deficient } & \multirow[b]{2}{*}{ ANOVA } \\
\hline & Fe Gluc & Fe- $\beta$ CPP & Fe Gluc & Fe- $\beta$ CPP & \\
\hline$N$ & 6 & 6 & 6 & 6 & \\
\hline Q1 & $51.3 \pm 1.9^{*}$ & $64.2 \pm 1.1^{a, b}$ & $60.9 \pm 2.9^{\mathrm{a}, \mathrm{b}}$ & $70.5 \pm 0.6^{a}$ & $P<0.001$ \\
\hline Q2 & $18.7 \pm 2.2$ & $15.2 \pm 1.9^{a, b}$ & $11.8 \pm 2.5^{\mathrm{a}, \mathrm{b}}$ & $15.0 \pm 3.4^{a}$ & $P<0.001$ \\
\hline $\mathrm{Fe}^{\mathrm{Abs}}$ & $32.6 \pm 3.3$ & $49.0 \pm 2.1^{a, b}$ & $49.1 \pm 4.6^{a, b}$ & $55.6 \pm 3.4^{a}$ & $P<0.001$ \\
\hline
\end{tabular}

*\% Moles perfused; mean $\pm 1 \mathrm{SD}$; initial iron concentration of the perfusion solution: $50 \mu \mathrm{M}$ (Fe Gluc or Fe- $\beta$ CPP); Q1: iron disappeared from digestive lumen; Q2: iron stored by the mucosa; Fe ${ }^{\mathrm{Ab}}$ : absorbed iron.

aDifferent $(P<0.05)$ from normal group Fe Gluc.

bifferent $(P<0.05)$ from deficient group Fe- $\beta$ CPP.

$\beta$-CPP-1-25 caseinophosphopeptide obtained from enzyme hydrolysis of $\beta$-casein. ANOVA-analysis of variance.

\section{Results}

\section{Initial hematologic data}

An ANOVA comparing the initial values of red blood cell counts (hemoglobin concentration and hematocrit) did not show any significant difference between the eight normal groups or between the eight Fe-deficient groups: $\mathrm{F}=1.06(P=$ $0.40)$ and $\mathrm{F}=0.92(P=0.39)$ for hemoglobin levels; $\mathrm{F}=1.08$ $(P=0.39)$ and $\mathrm{F}=1.76(P=0.12)$ for hematocrits. Therefore, the eight normal and Fe-deficient groups were pooled to assess the effect of bleeding. Mean hemoglobin $( \pm 1 \mathrm{SD})$ was $14.1 \pm 0.2$ and $10.4 \pm 0.2$ for normal and Fedeficient groups (Student's $t$-test, $t=93.9, P<0.0001$ ); mean hematocrit was $39.6 \pm 0.2$ and $29.5 \pm 0.3$ for normal and Fe-deficient groups (Student's $t$-test, $\mathrm{t}=190.9, P<0.0001$ ).

\section{Influence of Fe status and form of perfused $\mathrm{Fe}$ on its absorption}

Results are displayed in Table 1. Net Fe absorption was higher in Fe- $\beta$ CPP animals than in Fe Gluc animals, and higher in Fe-deficient rats than in control rats $(P<0.001)$. This is due to same differences in disappearance from digestive lumen $(P<0.001)$ and opposite trends in mucosal retention $(P<0.001)$.

\section{Influence of DNP}

In nondeficient groups, DNP inhibited by 50 to $60 \%$ the disappearance, by $40 \%$ the mucosal retention, and by $65 \%$ the net absorption of $\mathrm{Fe}$ compared with control animals (Figure 1). No differences were observed between Fe Gluc and Fe- $\beta$ CPP rats $(P<0.001)$. Similar results were obtained in Fe-deficient rats (Figure 2).

As a result, $11.4 \%$ and $7.5 \% \mathrm{Fe}$ were absorbed by a non-active pathway in Fe Gluc and Fe- $\beta$ CPP rats, respectively (Figure 3 ).

\section{Influence of PAO}

A significant inhibition of disappearance, mucosal retention, and net absorption of Fe was observed in Fe- $\beta$ CPP rats only. No effect of PAO was observed in Fe Gluc perfused animals.

Simultaneous perfusion of DNP and PAO resulted in an inhibition of $\mathrm{Fe}$ disappearance, mucosal retention, and net absorption equivalent to the sum of their individual effects (Figure 1 and Figure 2).

\section{Serum Fe}

Results are displayed in Table 2. At T1, ANOVA did not display any difference between the eight normal groups or between the eight Fe-deficient groups, and a subsequent comparison between the pooled results of normal and $\mathrm{Fe}-$ deficient T1 serum showed a significant effect of bleeding $(P<0.0001)$. A significant increase between the beginning and the end of the experiment was observed only in Fe Gluc rats, either control $(P<0.005)$ or Fe deficient $(P<0.005$; Student's $t$-test). This difference was still observed after PAO in these two groups $(P<0.005)$. No change was observed with DNP in control animals and $\mathrm{Fe}-\beta \mathrm{CPP}$ rats.

\section{Discussion}

Nutrient interactions have a great influence on Fe bioavailability. In particular, milk components such as calcium and proteins impair its absorption. ${ }^{15,16,30,31}$ Phosphoproteins such as caseins are strong ligands for $\mathrm{Fe}$ due to ionic and coordination bonds, ${ }^{9,11,12,32}$ which could release $\mathrm{Fe}$ too far in the digestive tract to be absorbed; in addition to this, during the formation of complexes $\mathrm{Fe}$ is oxidized into ferric ion, ${ }^{11,13}$ which is usually poorly absorbed because it becomes insoluble in digestive lumen at alkaline $\mathrm{pH} .{ }^{33}$ Dialyzability, and not only solubility, is predictive of protein induced absorption of $\mathrm{Fe}^{3,6}$ because whole proteins, and therefore bound cations, are assumed to be too large to diffuse across mucin. ${ }^{6}$ Indeed, although $\mathrm{Fe}$ solubility in the digestive tract is increased by presence of caseins, ${ }^{9,12}$ it is poorly absorbed, but this absorption is improved when milk proteins are hydrolyzed. ${ }^{15}$ Therefore, binding Fe to low molecular weight phosphopeptides issued from enzyme hydrolysis of casein should improve its digestive solubility and its absorption as well. Previous experimental studies in the young Fe-deficient rat showed that $\mathrm{Fe}$ bound to the purified $\beta \mathrm{CPP}$ has a better bioavailability than the reference salt $\left(\mathrm{FeSO}_{4}\right)$ or $\mathrm{Fe}$ bound to or in presence of whole $\beta$ casein. ${ }^{22}$ Despite an improvement in tissue storage and hemoglobin levels, this study was unable to display any difference in Fe absorption rate. However the metabolic balance was performed at the end of the first week of repletion, whereas in Fe-deficient rats $\mathrm{Fe}$ absorption seems to be increased only during the first 3 days of repletion. ${ }^{34}$ When Fe absorption is studied by the isolated, vascularized duodenal rat loop within 2 days after acute bleeding, $\beta$ CPP bound Fe displays a better 

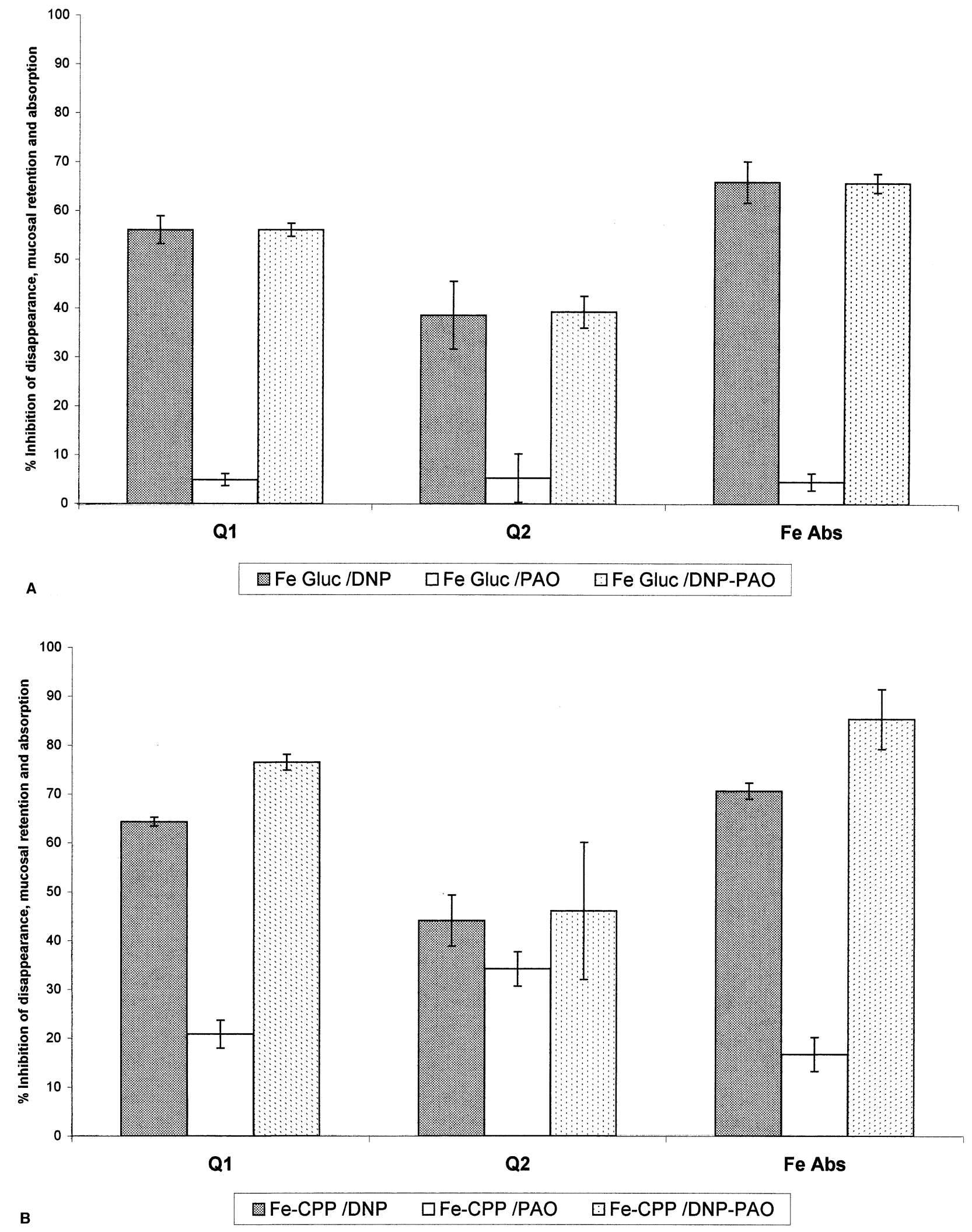

Figure 1 Inhibition of iron (Fe) absorption by 2-4 dinitrophenol (DNP) and/or phenylarsine oxide (PAO) in normal, nondeficient rats. Fe concentration of perfusion solution in every group is ( $A$ ) $50 \mu \mathrm{M}$ as iron gluconate or (B) $\beta$ casein ( $\beta$ CPP) bound iron. In control groups, no inhibitor was added. An oxidative phosphorylation inhibitor (DNP $500 \mu \mathrm{M}$ ) or an endocytosis inhibitor (PAO $100 \mu \mathrm{M}$ ), or both (DNP-PAO) were added. \%Q1, \%Q2, and \%Fe Abs as in Table 1. Inhibition of absorption is calculated from data of experiments with PAO \pm DNP compared with the mean value of the DNP or PAO free groups (\%); residual absorption is 100\% inhibition. 


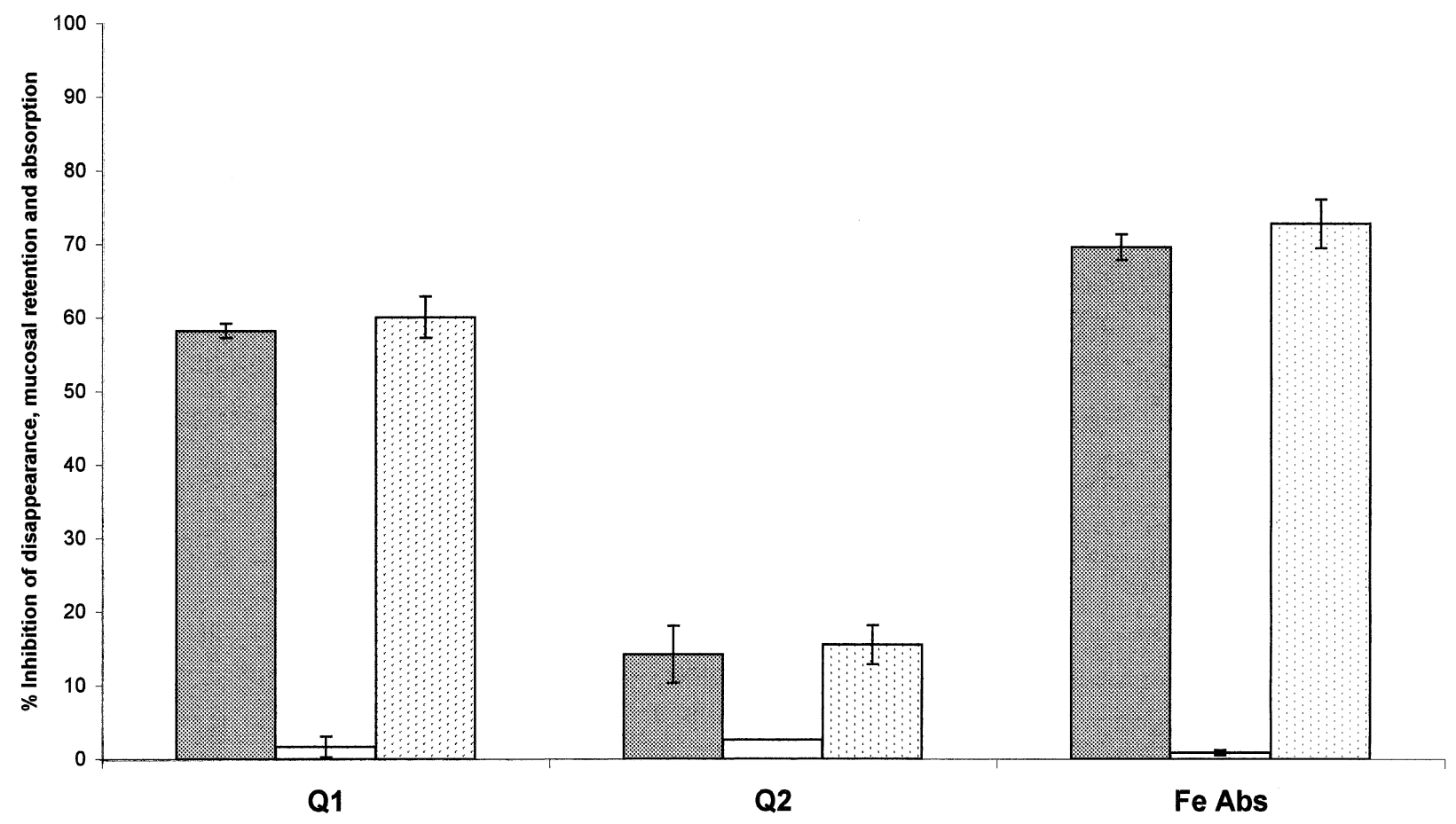

A $\square$ Fe Gluc deficient /DNP $\square$ Fe Gluc deficient /PAO $\square$ Fe Gluc deficient /DNP-PAO

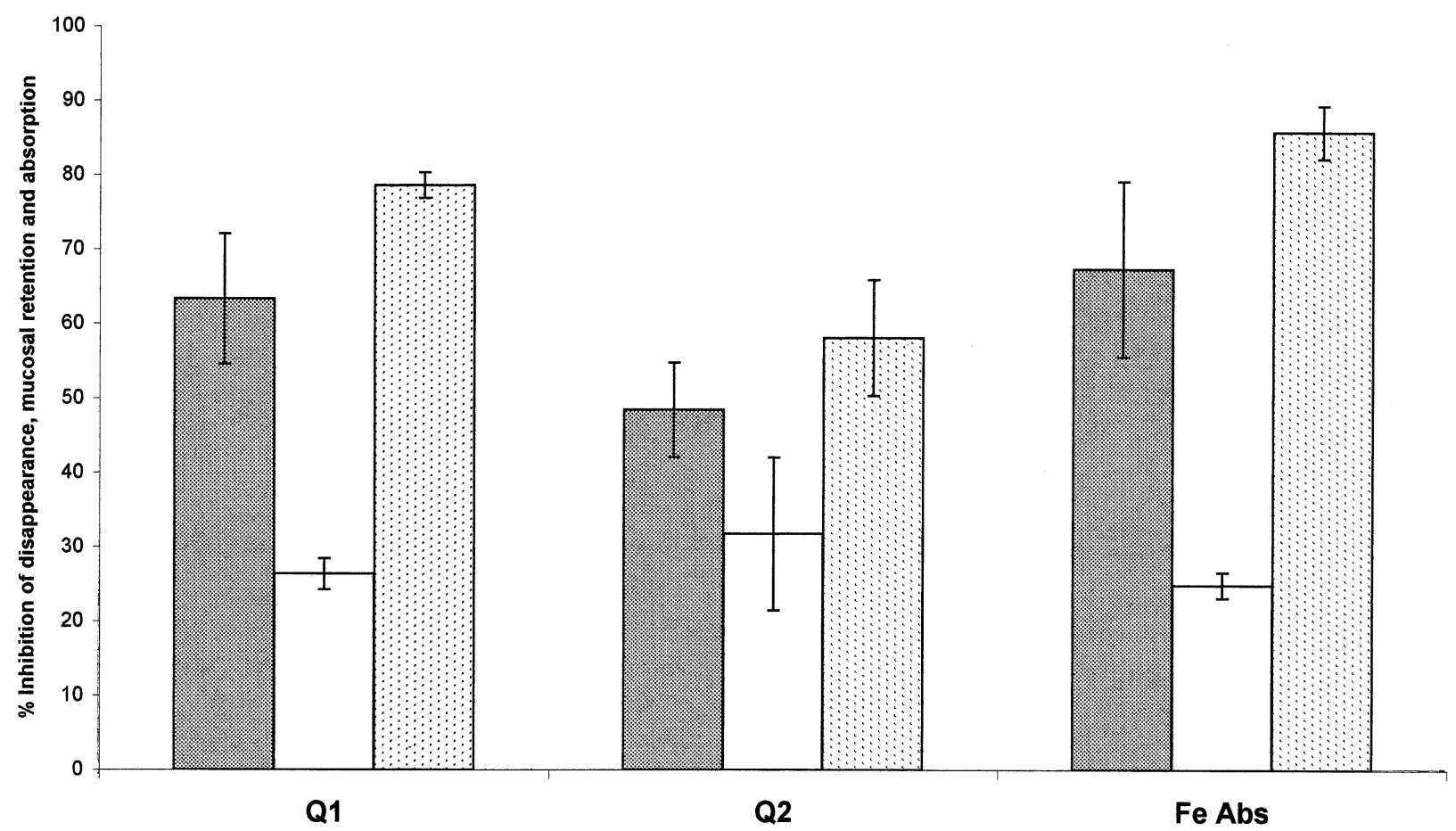

B

$\square$ Fe-CPP deficient /DNP $\square$ Fe-CPP deficient /PAO $\square$ Fe-CPP deficient /DNP-PAO

Figure 2 Inhibition of iron (Fe) absorption by 2-4 dinitrophenol (DNP), phenylarsine oxide (PAO), or DNP-PAO in Fe-deficient rats. Fe concentration of perfusion solution in every group is $(A) 50 \mu \mathrm{M}$ as iron gluconate or (B) $\beta$ casein ( $\beta$ CPP) bound iron. In control groups, no inhibitor was added. An oxydative phosphorylation inhibitor (DNP $500 \mu \mathrm{M}$ ) or an endocytosis inhibitor (PAO $100 \mu \mathrm{M}$ ), or both (DNP-PAO), were added. \%Q1, \%Q2, and \%Fe Abs as in Table 1. Inhibition of absorption is calculated from data of experiments with PAO \pm DNP compared with the mean value of the DNP or PAO free groups (\%); residual absorption is 100\% inhibition. 


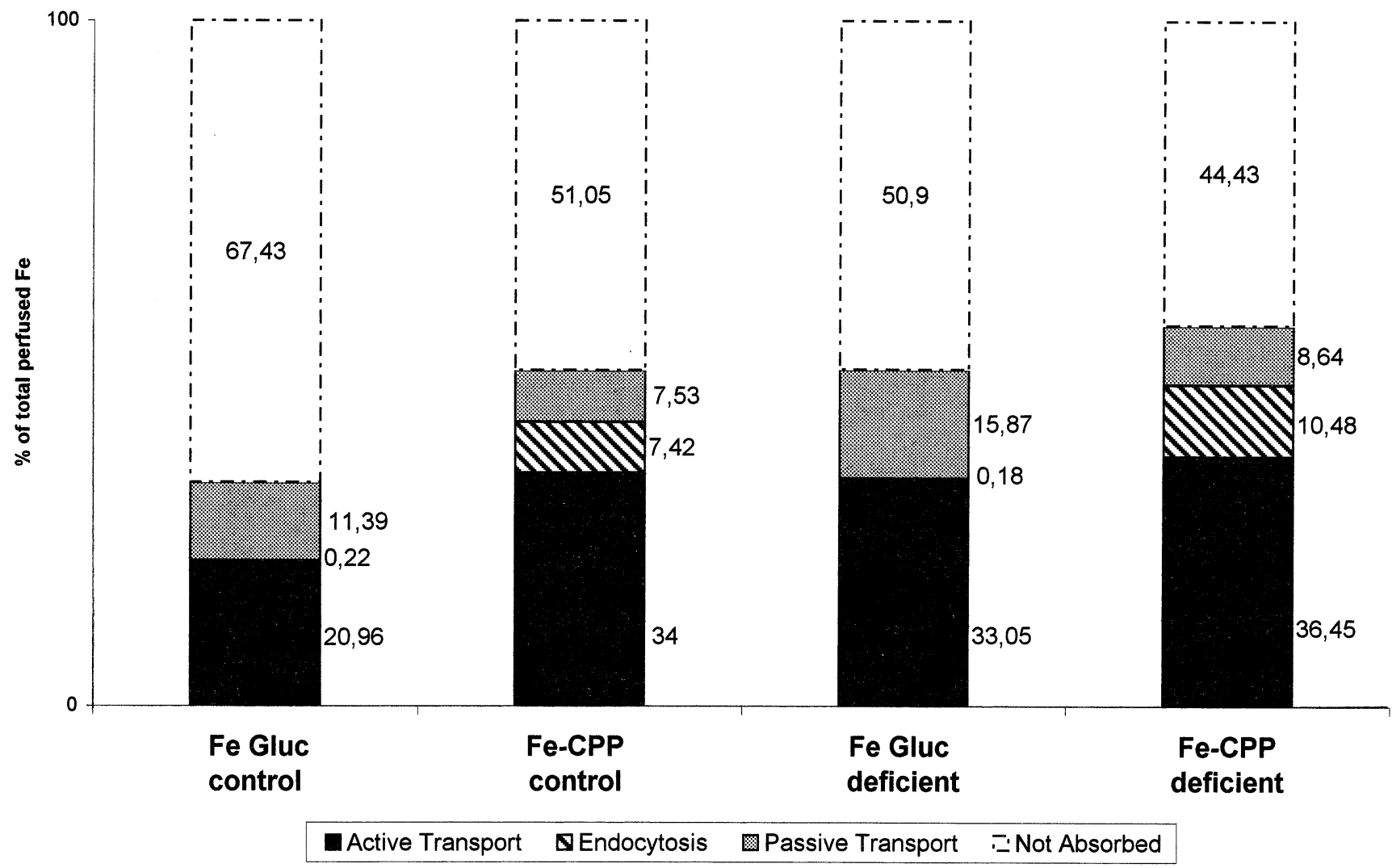

Figure 3 Relative contribution of respective pathways to iron (Fe) absorption according to its source and Fe status of animals. Absorption due to active or passive transport or endocytosis was calculated from data of Table 1 and from Figure 1 and Figure 2. Fe concentration of perfusion solution in every group is $50 \mu \mathrm{M}$ as iron gluconate or $\beta$ casein ( $\beta$ CPP) bound iron. In control groups, no inhibitor was added. An oxydative phosphorylation inhibitor [2-4 dinitrophenol (DNP) $500 \mu \mathrm{M}$ ] or an endocytosis inhibitor [phenylarsine oxide (PAO) $100 \mu \mathrm{M}$ ], or both (DNP-PAO), were added. \%Q1, \%Q2, and \%Fe Abs as in Table 1. Inhibition of absorption is calculated from data of experiments with PAO \pm DNP compared with the mean value of the DNP or PAO free groups (\%); residual absorption is $100 \%$ inhibition.

absorption rate than Fe Gluc and decreases the inhibitory effect of calcium. ${ }^{23} \mathrm{Fe}$ concentrations used in this work, however, were higher than usual dietary levels.
The present study was designed to confirm the enhancing effect of binding Fe to $\beta \mathrm{CPP}$, using the same experimental model at lower digestive Fe concentrations, and to assess

Table 2 Serum iron variations during duodenal rat loop perfusion with iron (Fe) bound to the $\beta$ caseinophosphopeptide (Fe- $\beta$ CPP) or Fe gluconate (Fe Gluc) in normal and Fe-deficient animals and influence of DNP or/and PAO addition to the perfusion

\begin{tabular}{|c|c|c|c|c|}
\hline $\mathrm{Fe}-\beta \mathrm{CPP}$ & $264.6 \pm 16.0$ & $268.2 \pm 13.5$ & $137.3 \pm 11.8$ & $139.2 \pm 15.4$ \\
\hline Fe Gluc DNP & $276.4 \pm 20.0$ & $285.3 \pm 20.2$ & $134.2 \pm 14.3$ & $138.1 \pm 17.0$ \\
\hline Fe- $\beta$ CPP DNP & $278.8 \pm 25.2$ & $280.7 \pm 22.0$ & $139.4 \pm 12.1$ & $141.1 \pm 15.6$ \\
\hline Fe Gluc PAO & $267.1 \pm 21.1$ & $301.3 \pm 23.1^{b}$ & $135.3 \pm 14.2$ & $179.2 \pm 13.6^{b}$ \\
\hline Fe- $\beta$ CPP DNP-PAO & $279.5 \pm 19.4$ & $286.8 \pm 23.6$ & $139.0 \pm 20.0$ & $142.2 \pm 18.9$ \\
\hline ANOVA between groups & $\mathrm{F}=0.88$ & & $\mathrm{~F}=0.18$ & \\
\hline Mean T1 & $\begin{array}{c}P=0.53 \\
273.4 \pm 19.6^{a}\end{array}$ & & $\begin{array}{c}P=0.99 \\
136.5 \pm 14.5\end{array}$ & \\
\hline
\end{tabular}

Iron was measured in serum before (T1) and at the end (T2) of intestinal perfusion. Composition of perfusion solutions were as in Figure 1. ${ }^{*} \mu \mathrm{g} / 100 \mathrm{~mL}$ mean $\pm 1 \mathrm{SD}$.

${ }^{a}$ Different (Student $t$-test: $\left.P<0.0001\right)$ from mean deficient group.

${ }^{b}$ Different (Student $t$-test: $P<0.005$ ) from T1.

DNP-2-4 dinitrophenol. PAO-phenylarsine oxide. 
the mechanisms involved in Fe- $\beta$ CPP absorption. It was assumed that some of this Fe could be absorbed in a bound form, according to the discovery of biologically active peptides issued from milk proteins in the serum of young animals and humans. This implies that they had crossed the digestive barrier. ${ }^{27}$ In the first case, our data confirmed our previous results that at a $50 \mu \mathrm{M}$ concentration $\mathrm{Fe}-\beta \mathrm{CPP}$ is better absorbed than Fe Gluc and, as expected, Fe deficiency enhanced $\mathrm{Fe}$ absorption irrespective of its form, suggesting that Fe- $\beta$ CPP absorption did not escape the regulation control. Fe- $\beta$ CPP improved net absorption of Fe, suggesting that binding $\mathrm{Fe}$ to $\beta \mathrm{CPP}$ influenced both $\mathrm{Fe}$ access to apical membrane, due to an increased solubility, and $\mathrm{Fe}$ metabolism inside the enterocyte.

DNP is a potent inhibitor of oxidative phosphorylation. Although a short-term (5 minutes) experiment did not show any effect of DNP on Fe uptake, ${ }^{35}$ another study used it to block efficiently the active transport of $\mathrm{Fe}^{36}$ This protocol does not allow differentiation between the different steps of absorption that could be inhibited by DNP during a 2-hour experiment: Absorption of $\mathrm{Fe}$ into the organism is energy dependent, the uptake phase being described both as energy independent and dependent. ${ }^{33,37}$ Nevertheless, gluconate and Fe- $\beta$ CPP absorption were similarly inhibited by DNP, suggesting that they share the same absorptive pathways and that the enhanced absorption of $\mathrm{Fe}-\beta$ CPP occurs through an added specific mechanism.

After energy dependent processes were abolished by DNP, 7 to $15 \%$ of Fe was still absorbed; passive absorption could be of physiologic importance because it depends on intraluminal concentrations and escapes homeostatic control; it could involve a paracellular pathway ${ }^{33}$ or passive diffusion across the apical membrane, beside the saturable active carrier mediated transport system. ${ }^{38}$ Because only $\mathrm{Fe}^{2+}$ - and not $\mathrm{Fe}^{3+}$ - seems to be concerned by this uptake mechanism, free ferric ion yielded from Fe- $\beta$ CPP cleavage should have been reduced into a ferrous form by a membrane reductase before being taken up. ${ }^{39,40}$ Passive absorption was slightly enhanced by $\mathrm{Fe}$ deficiency, perhaps as a result of a diminished intracellular concentration of Fe, such as previously reported ${ }^{36,41}$; however, an increase of the active component of absorption also has been described. ${ }^{42}$ Passive Fe absorption was enhanced neither by $\beta$ CPP, such as reported for calcium, ${ }^{43}$ nor by the increased intestinal permeability induced by $\mathrm{Fe}$ deficiency such as has been reported in children. ${ }^{44}$

PAO is a ubiquitous inhibitor of endocytosis. ${ }^{45-47}$ It had absolutely no effect on Fe Gluc absorption; cytoskeletal inhibitors such as colchicine were previously reported to affect $\mathrm{Fe}^{3+}$ absorption ${ }^{48,49}$; in fact, colchicine probably does not affect endocytosis per se, but acts rather on the intracellular migration. ${ }^{50}$ On the other hand PAO decreased by 20 to $30 \%$ the uptake and net absorption of $\beta$ CPP bound $\mathrm{Fe}$, which seems to be absorbed by this specific pathway, perhaps being bound to an amino acid or a peptide. Biologically active peptides issued from enzyme digestion of casein have been found intact in plasma ${ }^{26,27}$; dietary peptides and proteins can be taken up by endocytosis and transported through the digestive epithelium; approximately $10 \%$ can be absorbed in an intact form. ${ }^{26,51} \mathrm{Fe}$ is slowly cleaved from $\beta \mathrm{CPP}^{12} ; \beta \mathrm{CPP}$ is partially resistant to enzyme hydrolysis ${ }^{12,24}$ and is found in feces. ${ }^{7,16}$ Therefore, a large part of Fe- $\beta$ CPP could remain intact in duodenum lumen, allowing $\mathrm{Fe}$ to be taken up by endocytosis, together with $\beta$ CPP or any derived peptide.

The occurrence of distinct absorption pathways between Fe Gluc and Fe- $\beta$ CPP also is suggested by the differences observed between changes in Fe serum levels, which increased during experiments with $\mathrm{Fe}$ Gluc and remained unchanged with $\mathrm{Fe}-\beta \mathrm{CPP}$. Plasma $\mathrm{Fe}$ issued from $\mathrm{Fe}-\beta$ CPP could have been cleared more efficiently than Fe Gluc. This is in agreement with the previous observation of increased tissue storage in rats fed Fe- $\beta$ CPP. ${ }^{22} \mathrm{Fe}$ stored by rats during Fe- $\beta$ CPP feeding is available for synthesis of hemoglobin, which reaches normal levels at the end of repletion, whereas $\mathrm{FeSO}_{4}$ repleted animals still exhibit lower values. ${ }^{22}$ Such a discrepancy between absorption and serum levels is observed when milk proteins are added to a test meal during a study of zinc absorption..$^{51}$ Metabolism of selenium also is influenced by this form: When it is provided as selenomethionine, its availability depends on the release of methionine by tissues. ${ }^{52}$

\section{Conclusions}

The present study confirms that $\beta$ CPP bound Fe has a better bioavailability than inorganic salts. This could be explained by the occurrence of distinct absorption pathways: Part of Fe- $\beta$ CPP was absorbed by endocytosis, in addition to the usual passive and energy dependent mechanisms. The enhanced absorption of Fe- $\beta$ CPP was observed in normal and Fe-deficient animals. It is clear that further studies are needed to assess these beneficial effects in humans.

\section{Acknowledgments}

JMP is recipient of a grant from the Ministère de la Recherche et de l'Enseignement Supérieur .

\section{References}

1 Conrad, M.E., Umbreit, J.N., and Moore E.G. (1991). A role for mucin in the absorption of inorganic iron and other metal cations. Gastroenterology 100, 129-136

2 Conrad, M.E. (1993). Regulation of iron absorption. J. Am. Coll. Nutr. 6, 720-728

3 Kane, A.P. and Miller, D.D. (1984). In vitro estimation of the effects of selected proteins on iron bioavailability. Am. J. Clin. Nutr. 39, 393-401

4 Kim, M., Lee, D.T., and Lee, Y.S. (1995). Iron absorption and intestinal solubility in rats are influenced by dietary proteins. Nutr. Res. 15, 1705-1716

5 Slatkavitz, C.A. and Clydesdale, F.M. (1988). Solubility of inorganic iron as affected by proteolytic digestion. Am. J. Clin. Nutr. 47, 487-495

6 Miller, D.D. and Berner, L.A. (1989). Is solubility in vitro a reliable predictor of iron bioavailability? Biol. Trace Elem. Res. 19, 11-24

7 West, D.W. (1986). Structure and function of the phosphorylated residues of casein. J. Dairy Res. 53, 333-352

8 Meisel, H. and Frister, H. (1989). Chemical characterization of bioactive peptides from in vivo digest of casein. J. Dairy Res. 56, 343-349

9 Brulé, G. and Fauquant, J. (1982). Interactions des protéines du lait. Lait 62, 323-331

10 Baumy, J.J., Guenot, P., Sinbandhit, S., and Brulé, G. (1989). Study of calcium binding to phosphorine residues of $\beta$-casein and its phosphopeptide (1-25) by ${ }^{31}$ P. J. Dairy Res. 56, 403-409 
11 Demott, B.J. and Dincer, B. (1976). Binding added iron to various milk proteins. J. Dairy. Sci. 59, 1557-1559

12 Bouhallab, S., Léonil, J., and Maubois, J.L. (1991). Complexation du fer par le phosphopeptide (1-25) de la caséine $\beta$ : Action de l'alcalase et de la phosphatase acide. Lait 71, 435-443

13 Emery, T. (1992). Iron oxidation by casein. Biochem. Biophys. Res. Commun. 182, 1047-1052

14 Scanff, P., Yvon, M., and Pelissier J.P. (1991). Immobilized $\mathrm{Fe}^{3+}$ affinity chromatographic isolation of phosphopeptides. J. Chromatogr. 539, 425-432

15 Hurell, R.F., Lynch, S.R, Trinidad, P., Dassenko, S.A., and Cook, J.D. (1989). Iron absorption in humans as influenced by bovine milk proteins. Am. J. Clin. Nutr. 49, 546-552

16 Sato, R., Noguchi, T., and Naito, H. (1986). Casein phosphopeptide enhances calcium absorption from ligated segment of rat small intestine. J. Nutr. Sci. Vitaminol. 32, 67-76

17 Yuan, Y.V. and Kitts, D.D. (1991). Confirmation of calcium absorption and femoral utilization in spontaneously hypertensive rats fed casein phosphopeptide supplemented diets. Nutr. Res. 11, 12571272

18 Pointillart, A. and Gueguen, L. (1989). Absence d'effet de l'incorporation d'un phosphopeptide du lait sur l'utilisation du calcium et du phosphore chez le jeune porc. Reprod. Nutr. Dev. 29, $477-486$

19 Li, Y., Tome, D., and Desjeux, J.F. (1989). Indirect effect of casein phosphopeptides on calcium absorption in rat ileum in vitro. Reprod. Nutr. Develop. 29, 227-233

20 Hansen, M., Sandström, B., and Lönnerdal, B. (1996). Casein phosphopeptides improve zinc and calcium absorption from ricebased but not whole-grain infant cereal. J. Pediatr. Gastroenterol. Nutr. 24, 56-62

21 Hansen, M., Sandström, B., and Lönnerdal, B. (1996). The effect of casein phosphopeptides on zinc and calcium absorption from high phytate infant diets assessed in rats pups and Caco-2 cells. Pediatr. Res. 40, 547-552

22 Aït-Oukhatar, N., Bouhallab, S., Bureau, F., Arhan, P., Maubois, J.L., Drowdowsky, M.A., and Bouglé, D. (1997). Bioavailability of caseinophosphopeptide bound to iron in the young rat. J. Nutr. Biochem. 8, 190-195

23 Pérès, J.M., Bouhallab, S., Bureau, F., Maubois, J.L., Arhan, P., and Bouglé, D. (1997). Absorption digestive du fer lié au caséinophosphopeptide 1-25 de la $\beta$-caséine. Lait 77, 433-440

24 Brommage, R., Juillerat, M.A., and Jost, R. (1991). Influence of casein phosphopeptides and lactulose on intestinal calcium absorption in adult female rats. Lait 62, 323-331

25 Caillard, I. and Tomé, D. (1995). Transport des antigènes protéiques majeurs du lactosérum bovin dans l'épithélium intestinal. Cah. Nutr. Diet. 30, 306-312

26 Mahé, S., Tomé, D., Dumontier, A.-M., and Desjeux, J.F. (1989). Absorption of intact $\beta$-casomorphins ( $\beta-\mathrm{CM})$ in rabbit ileum in vitro. Reprod. Nutr. Dev. 29, 725-732

27 Maubois, J.L. and Léonil, J. (1989). Peptides du lait à activité biologique. Lait 69, 245-269

28 Hurrel, R.F. (1992). Prospects for improving the iron fortification of foods. In Nutritional Anemias (S.J. Fomon and S. Zlotkin, eds.), pp. 193-208, Raven Press, New York, NY, USA

29 Brulé, G., Roger, L., Fauquant, J., and Piot, M. (1980). Procédé de traitement d'une matière première à base de caséine, contenant des phosphocaséinates des cations bivalents, produits obtenus et applications. Brevet français $\mathrm{n}^{\circ} 8002280$

30 Hydén, S. (1955). A turbidimetric method for the determination of higher polyethylene glycols in biological materials. Kungl. Lantbrukshögskolans Annaler 22, 139-145

31 Hallberg, L., Brune, M., Erlandsson, M., Sandberg, A.S., and Rossander-Hultén, L. (1991). Calcium: Effect of different amounts on nonheme- and heme-iron absorption in humans. Am. J. Clin. Nutr. 53, $112-119$

32 Barton, J.C., Conrad, M.E., and Parmley, R.T. (1983). Calcium inhibition of inorganic iron absorption in rats. Gastroenterology 84, 90-101

33 Hegenauer, J., Saltman, P., Ludwig, D., Ripley, L., and Ley, A. (1979). Iron-supplemented cow milk. Identification and spectral properties of iron bound to casein micelles. J. Agr. Food Chem. 27, 1294-1301
34 Beard, J.L., Dawson, H., and Pinero. D.J. (1996). Iron metabolism: A comprehensive review. Nutr. Rev. 54, 295-317

35 Viteri, F.E., Xunian, L., Tolomei, K., and Martin, A. (1995). True absorption and retention of supplemental iron is more efficient when iron is administered every three days rather daily to iron-normal and iron-deficient rats. J. Nutr. 125, 82-91

36 Nichols, G.M., Pearce, A.R., Alverez, X., Bibb, N.K., Nichols, K.Y., Alfred, C.B., and Glass, J. (1992). The mechanisms of nonheme iron uptake determined in IEC-6 rat intestinal cells. J. Nutr. 122, 945-952

37 Campos, M.S., Gomez-Ayala, A.E., Lopez-Aliaga, I., Pallarés, I., Hartiti, S., Alférez, M.J.M., Barrionuevo, M., Rodriguez-Matas, M.C., and Lisbona, F. (1996). Role of the proximal colon in mineral absorption in rats with and without ferropenic anemia. Nutr. Res. 16, $1529-1543$

38 Conrad, M.E. (1993). Regulation of Iron Absorption. Essential Toxic Trace Elements in Human Health and Disease: An Update. WileyLiss, New York, NY, USA

39 Stremmel, W., Lotz, G., Niederau, C., Teschke, R., and Strohmeyer, G. (1987). Iron uptake by rat duodenal microvillous membranes vesicles: Evidence for a carrier mediated transport system. Eur. J. Clin. Invest. 17, 136-145

40 Riedel, H.D., Remus, A.J., Fitscher, B.A., and Stremmel, W. (1995). Characterization and partial purification of a ferrireductase from human duodenal microvillus membranes. Biochem. J. 309, 745-748

41 Ekmekcioglu, C., Feyertag, J., and Marktl W. (1996). A ferric reductase activity is found in brush border membrane vesicles isolated from Caco-2 cells. J. Nutr. 126, 2209-2217

42 Zhang, D. and Mahoney, A.W. (1989). Bioavailability of iron-milkprotein complexes and fortified cheddar cheese. J. Dairy Sci. 72, 2845-2855

43 Huebers, H.A., Csiba, E., Josephson, B., and Finch, C.A. (1990). Iron-absorption in the iron-deficient rat. Gut 60, 345-351

44 Nagasawa, T., Yuan, Y.V., and Kitts, D.D. (1991). Casein phosphopeptides enhance paracellular calcium absorption but do not alter temporal blood pressure in normotensive rats. Nutr. Res. 11, 819-830

45 Berant, M., Khourie, M., and Menzies, I.S. (1992). Effect of iron deficiency on small intestinal permeability in infants and young children. J. Pediatr. Gastr. Nutr. 14, 17-20

46 Watanabe, J., and Muranishi, H., Yuasa, H. (1993). Uptake mechanism of fractionated $\left[{ }^{3} \mathrm{H}\right]$ Heparin in rat parenchymal hepatocytes in primary culture: Effect of transport inhibitors on the uptake. Biol. Pharm. Bull. 16, 497-500

47 Nakai, D., Seita, T., Terasaki, T., Iwasa, S., Shoji, Y., Mizushima, Y., and Sugiyama, Y. (1996). Cellular uptake mechanism for oligonucleotides: Involvement of endocytosis in the uptake of the phosphodiester oligonucleotides by a human colorectal adenocarcinoma cell line, HCT-15. J. Pharmacol. Exp. Ther. 278(3), 1362-1372

48 Becker, B.N. and Harris, R.C. (1996). A potential mechanism for proximal tubule angiotensine II-mediated sodium flux associated with receptor-mediated endocytosis and arachidonic acid release. Kidney Int. Suppl. 57, S66-S72

49 Johnson, G., Jacobs, P., and Purves, L.R. (1985). The effects of cytoskeletal inhibitors on intestinal iron absorption in the rat. Biochim. Biophys. Acta 843, 83-91

50 Simpson, R.J., Osterloh, K.R.S., Raja, K.B., Snape, S.D., and Peters, T.J. (1986). Studies on the role of transferrin and endocytosis in the uptake of $\mathrm{Fe}^{3+}$ from Fe-nitrilotriacetate by mouse duodenum. Biochim. Biophys. Acta 884, 166-171

51 Gruenberg, J., Griffiths, G., and Howell, K.E. (1989). Characterization of the early endosome and putative endocytic carrier vesicles in vivo and with an assay of vesicle fusion in vitro. J. Cell. Biol. 108, 1301-1316

52 Caillard, I. and Tomé, D. (1992). Different routes for the transport of b-lactalbumin in the rabbit ileum. J. Nutr. Biochem. 3, 653-658

53 Sandström, B., Arvidsson, B., Cederblad, A., and Björn-Rasmussen, E. (1980). Zinc absorption from composite meals I. The significance of wheat extraction rate, zinc, calcium, and protein content in meals based on bread. Am. J. Clin. Nutr. 33, 739-745

54 Nève, J. (1995). Human selenium supplementation as assessed by changes in blood selenium concentration and glutathione peroxidase activity. J. Trace. Elem. Med. Biol. 9, 65-73 